\title{
Citra Diri Mahasiswi Obesitas di Universitas Islam Negeri Raden Fatah
}

\section{Palembang}

\author{
Syarifah Faizah ${ }^{\mathbf{a}^{*}}$, Ris'an Rusli ${ }^{\text {b }}$, Budiman ${ }^{\mathrm{c}}$ \\ ${ }_{a, b, c}$ Universitas Islam Negeri Raden Fatah Palembang \\ *Corresponding author: dofaizah1@gmail.com
}

\begin{abstract}
Abstrak
Penelitian ini membahas citra diri mahasiswi obesitas di UIN Raden Fatah. Penelitian ini menggunakan penelitian kualitatif deskripsi. Subjek penelitian ini terdiri dari empat mahasiswi obesitas. Informan tahu dalam penelitian ini merupakan teman dekat subjek. Berdasarkan hasil penelitian ini keempat subjek memiliki citra diri positif, namun pada kondisi tertentu dapat menjadi citra diri negatif. Seperti, pada salah satu karakteristi citra diri positif yaitu kepercayaan diri, pada subjek pertama sangat percaya diri, namun mengaku pernah merasa minder jika berada dalam suasana hati yang buruk. Pada subjek kedua merasa kurang percaya diri, namun merasa percaya diri jika berada di kampus. Pada subjek ketiga hanya merasa percaya diri jika bersama keluarga, teman dekat dan orang-orang yang mengenalnya, namun jika dengan orang lain merasa tidak percaya diri, karena mengangap pandangan masyarakt terhadap orang obesitas adalah menyusahkan. Sama halnya, dengan subjek keempat yaitu merasa percaya diri jika besama keluraga dan teman dekatnya saja.
\end{abstract}

\author{
Kata Kunci \\ Citra Diri; Obesitas; Mahasiswa
}

\begin{abstract}
This research discusses the self-image of obesity students at UIN Raden Fatah. This study uses descriptive qualitative research. The subject of this study consisted of four obese students. Informants know in this study are close friends of the subject. Based on the results of this study the four subjects had a positive self-image, but in certain conditions it could be a negative selfimage. Like, in one of the characteristics of a positive self-image that is self-confidence, the first subject was very confident, but claimed to have felt inferior if he was in a bad mood. In the second subject, they felt less confident, but felt confident when they were on campus. In the third subject only feel confident if with family, close friends and people who know her, but if with other people feel insecure, because considering the public view of obese people is troublesome. The same is true, with the fourth subject, feeling confident if only with her family and close friends.
\end{abstract}

Keywords

Self-Image; Obesity; Students 


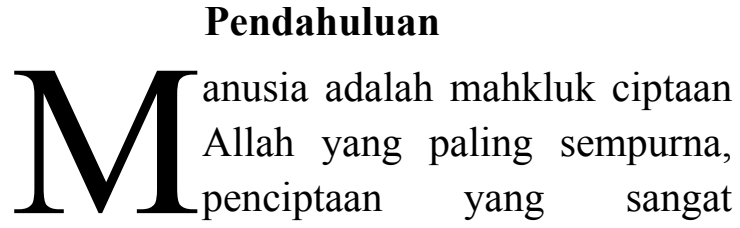

sempurna baik fisik maupun non fisik seperti akal, qalb (hati), tanpa kehilangan syahwat dan nafsu, dan juga gerak motorik seluruh tubuhnya yang demikian indah dan dinamis. Dengan begitu, manusia dianugerahkan berbagai kelebihan, dan kelebihan-kelebihan tersebut tidak diberikan Allah kepada makhluk lain selain manusia dan hal ini pula yang menyebabkan mereka memperoleh kemuliaan-Nya. Firman Allah SWT, QS. Al-Isra ayat 70, yang menjelaskan tentang manusia adalah makhluk yang sempurna. Begitu juga Allah menciptakan manusia dengan bentuk sebaik-baiknya. Sebagaimana dalam firman Allah SWT QS. At-Tin ayat 4 , yang menyatakan manusia diciptakan dalam bentuk yang sebaikbaiknya.

Begitu banyak kelebihan yang telah diberikan Allah yang tidak diberikan kepada makhluk ciptaan yang lain selain manusia, yang harus kita syukuri. Begitu juga kenikmatan-kenikmatan kecil yang sering kita abaikan. Menurut Lutfiana (2017), Allah SWT memberikan kita nikmat yang tidak terhingga setiap harinya. Hanya saja, kita tidak menyadari hal tersebut. Setiap napas yang kita hirup, setiap tubuh yang kita gerakkan, itu semua merupakan nikmat yang Allah berikan tanpa kita sadari. Tetapi, sering kali manusia tidak mensyukuri hal-hal kecil, seperti tubuh yang sehat yang diberikan Allah SWT. Dalam QS. Al-Mulk ayat 23 yang menerangkan tentang Allah SWT yang memberi pendengaran, penglihatan dan hati, tapi sangat sedikit yang mensyukurinya.

Sering kali manusia merasa tidak puas dengan penampilan fisiknya terutama wanita, sebagai seorang wanita tentu mendambakan penampilan fisik yang sempurna, seperti memiliki tubuh yang ideal; bertubuh tinggi diatas rata-rata dan bertubuh ramping, memiliki wajah rupawan dan senyum menawan. Sayangnya tidak semua orang memilikinya, karena itu, banyak yang tidak puas dengan penampilan fisiknya. Hal ini, dikhawatirkan dapat berpengaruh buruk pada wanita tersebut. Menurut Devya (2015) penampilan fisik adalah satu-satunya yang mampu menarik teman sebayanya maupun lawan jenisnya. Mereka cenderung lebih mementingkan daya tarik fisik dalam proses sosialisasi. Menurut Pandu (2014) pada remaja putri khususnya, perubahan penampilan fisik akan lebih terlihat dari sebelumnya. Kelebihan berat badan dari ukuran ideal atau biasa disebut dengan obesitas merupakan suatu hal yang ditakuti oleh banyak remaja putri, karena dapat merusak penampilan dan citranya sebagai seorang wanita.

Oktarina, dkk. (2010) mengatakan obesitas adalah kelebihan bobot badan sebagai akibat dari penimbunan lemak tubuh yang berlebihan. Tubuh yang obesitas memilik lemak berlebih yang disebabkan oleh asupan kalori sehari-hari yang berlebihan. Menurut Nur'afni (2009) obesitas adalah penumpukan jaringan lemak tubuh yang abnormal. Hal yang bisa menyebabkan obesitas adalah asupan kalori dalam tubuh yang tidak sesuai (berlebihan) dengan kalori yang dikeluarkan. 
Obesitas sekarang ini sudah menjadi masalah global, jumlah orang yang mengalami obesitas cukup banyak tidak hanya di negara-negara maju tapi juga, di negara-negara berkembang. Menurut Chan dan Woo (2010) obesitas merupakan masalah kesehatan yang terjadi di masyarakat yang telah menimbulkan kekhawatiran diseluruh dunia.

Data pada tahun 2008 yang dikeluarkan oleh organisasi kesehatan dunia atau World Health Organization (WHO) menunjukkan bahwa lebih dari 1,4 miliar orang dewasa berusia di atas 20 tahun mengalami kelebihan berat badan. Jumlah tersebut lebih banyak dialami oleh perempuan dibandingkan laki-laki. Selanjutnya Behavior Risk Factor Surveilance System (BRFSS) menyatakan bahwa 19,4\% wanita di Amerika Serikat, secara klinis mengalami obesitas (IMTatau Indeks Massa Tubuh $>30 \mathrm{~kg} / \mathrm{m}^{2}$ ). World Health Organization (WHO) pada tahun 2008 menunjukkan bahwa 300 orang perumpuan dewasa menderita obesitas. Sementara itu, hanya sekitar 200 orang laki-laki dewasa yang menderita obesitas (dalam Sudargo, dkk., 2014).

Menurut World Health Organization (WHO) (dalam Chan \& Woo, 2010) Meskipun beberapa negara-negara maju seperti Inggris dan Jerman mengalami penurunan tingkat prevalensi obesitas dalam dekade terakhir, tetapi prevalensi obesitas terus meningkat di banyak bagian dunia, terutama di kawasan Asia Pasifik. Sebagai contoh, prevalensi gabungan kelebihan berat badan dan obesitas meningkat $46 \%$ di Jepang dari $16,7 \%$ di 1976-1980 menjadi $24,0 \%$ pada tahun 2000, dan di China dari 3,7\% pad a tahun 1982 menjadi $19,0 \%$ pada tahun 2002 .
Di Indonesia, angka obesitas terus meningkat secara drastis dari tahun ke tahun. Prevalensi obesitas berdasarkan Riskesdas (Riset kesehatan dasar) tahun 2010 (dalam Akhriani, dkk., 2016) adalah 2,5\% untuk kelompok usia 13-15 tahun, sedangkan berdasarkan Riskesdas (Riset kesehatan dasar) 2013 prevalensi ini meningkat menjadi $10,8 \%$. Dapat dilihat bahwa angka obesitas pada remaja meningkat $8,3 \%$ dalam kurun waktu 3 tahun. Hal tersebut memberikan peringatan bahwa terdapat kemungkinan terjadinya peningkatan angka obesitas remaja di masa yang akan datang. Remaja dengan obesitas memiliki kemungkinan untuk menjadi obesitas di masa dewasa sekitar 40\% sampai $59,9 \%$.

Penderita obesitas lebih rentan terserang penyakit, berbagai macam resiko penyakit berbahaya dapat menyerang orang berbadan obesitas. Rosmala (2006) menjelaskan penderita obesitas lebih sering sakit. Obesitas pada wanita bisa menimbulkan kelainan haid, kemandulan, keputihan, penyakit kulit di lipatan paha dan payudara, dan keracunan kehamilan. Obesitas juga menjadi 'pintu gerbang' datangnya penyakit-penyakit degeneratif, seperti tekanan darah tinggi, diabetes melitus, jantung, stroke, dan kanker, penderita obesitas pun mempunyai angka harapan hidup yang lebih rendah dari populasi berat badan normal.

Menurut Winarsi (2010) sebagai akibat lebih jauh dari obesitas, penderita akan mengalami gangguan kesehatan seperti meningkatnya risiko penyakit kardiovaskuler, kanker, stroke, diabetes, osteoarthritis, gallbladder disease, "sleep opnea" (tidak bisa bernapas saat tidur), 
serta tingkat kematian yang lebih tinggi dibanding individu berberat badan normal. Penderita obesitas berisiko 30 kali lebih besar terkena diabetes mellitus tipe-2 dibanding orang dengan berat badan normal. Dan bila indeks massa tubuhnya meningkat hingga lebih dari 35, maka kemungkinan terkena diabetes tipe-2 menjadi 90 kali lipat.

Orang yang menderita obesitas juga banyak mengalami kesulitan menjalankan aktivitas sehari-hari. Menurut Rosmala (2006) seorang yang mengidap obesitas mempunyai banyak kesulitan dalam melakukan aktivitas fisik sehari-hari. Pengeluaran sehari-hari untuk pakaian dan makanan lebih besar daripada orang normal, penderita bisa mengalami rasa tidak percaya diri, tertekan, dan putus asa.

Seseorang yang mengalami obesitas sulit untuk berhubungan dengan orang lain, dimana penampilan fisik menjadi penentu yang penting dalam menjalin hubungan dengan orang lain, karena hubungan akan berjalan dengan baik jika kesan pertama yang ditimbulkan adalah kesan yang baik. Dari kesan pertama itulah akan terbentuk penilaan orang lain terhadap diri seseorang, dan barulah citra diri atau gambaran dirinya terbentuk. Holden (2005) mengatakan citra diri terbentuk dari penilaian yang dibuat oleh kita sendiri maupun oleh orang lain. Citra diri ini merupakan "Diri yang dipelajari". Ia terbentuk dari informasi pengalaman, umpan balik, dan kesimpulan yang di buat.

Seringkali, dari penilaian-penilaian orang lain terhadap diri seseorang itulah yang menjadi pemikiran tentang diri, dan itulah yang dia gambarkan tentang dirinya. Menurut Wibowo (2007) citra diri adalah pandangan tentang diri atau bagaimana menggambarkan diri itu sendiri. Citra diri inilah yang menbedakan seorang manusia dengan manusia lain, yaitu bagaimana ia memandang dirinya sendiri. Pandangan ini bervariasi antara satu orang dengan orang yang lainnya. Ada orang berpandangan sangat baik, optimistis, dan positif terhadap dirinya, namun ada juga yang menganggap dirinya rendah dan tidak berguna.

Dari uraian di atas, maka dapat disimpulkan pada umumnya orang yang obesitas memiliki citra diri yang negatif. Hal tersebut justru bertentangan dengan fenomena yang terjadi, dilihat dari penelitian sebelumnya yang meneliti tentang obesitas baik secara kualitatif maupun kuantitatif.

Kesimpulan dari hasil penelitan tersebut, menurut Wulandari dan Aini (2016) menyimpulkan didapatkannya hasil terbanyak yaitu 48 orang (56.5\%) remaja putri dengan harga diri positif. Sedangkan, penelitian Sitepu (2016) juga melakukan hal yang sama, penelitian ini menyimpulkan hasil tingkat keprcayaan diri dibagi menjadi tiga kategori: Kepercayaan diri tinggi sebesar 65\% (40 orang), sedang $35 \%$ (22 orang), dan rendah tidak ada.

Kemudian, kesimpulan hasil penelitian tentang citra diri dan obesitas, dari Ningsi dan Jana (2016) menemukan hasil responden yang memiliki citra diri positif lebih banyak dari pada yang memiliki citra diri negatif, yaitu orang obesitas yang memiliki citra diri positif sebanyak 24 orang $(63 \%)$ dan orang obesitas yang memiliki citra diri negatif sebanyak 14 orang (37\%). Sedangkan, Prameswari, dkk. (2013) menyimpulkan penelitiannya 
menunjukan hasil yang tidak jauh berbeda, yaitu sebanyak 14 remaja putri obesitas memiliki citra diri negatif dan harga diri rendah dan sebanyak 13 remaja putri obesitas memiliki citra diri positif dan harga diri tinggi.

Sejalan dengan hasil penelitian diatas, dari hasil wawancara yang telah dilakukan terhadap mahasiswi UIN Raden Fatah Palembang penyandang obesitas yang dijadikan sebagai subjek bernama RA. ketika diajukan pertanyaan perihal bagaimana pandangan RA terhadap dirinya. Dan dari jawaban RA mengatakan bahwa, dirinya adalah orang yang percaya diri, dan dapat menjadi dirinya sendiri.

Berdasarkan uraian diatas maka penulis tertarik mendapatkan gambaran mendalam tentang citra diri mahasiswi obesitas di Universitas Islam Negeri Raden Fatah Palembang. Selain itu alasan penulis memilih lokasi di Universitas Islam Negeri Raden Fatah Palembang karena belum pernah dilakukan penelitian sejenis sebelumnya di Universitas tersebut.

\section{Metode}

Masalah yang akan diungkap dalam penelitian ini adalah citra diri pada mahasiswi yang mengalami obesitas. Untuk itu, pendekatan deskriptif kualitatif dipandang sesuai untuk dapat mengetahui bagaimana citra diri pada mahasiswi yang mengalami obesitas. Penelitian kualitatif menurut Maleong (2017) penelitian kualitatif bermaksud untuk memahami latar belakang subjek penelitian, misalnya tentang motivasi, peranan, nilai, sikap, dan persepsi. Hanurawan (2016) Penelitian kualitatif dalam psikologi adalah prosedur sistematik (metode) yang disepakati oleh suatu komunitas ilmiah ilmu psikologi untuk mengungkap suatu makna subjektif partisipan penelitian tentang suatu gejala yang menjadi objek kajian penelitian bidang ilmu psikologi. Dalam hal ini objek penelitian psikologi adalah fenomena mental dan prilaku manusia.

Metode yang digunakan dalam pengumpulan data penelitian ini ialah dengan teknik observasi, wawancara, dan dokumentasi. Teknik yang digunakan dalam penelitian kualitatif dengan pendekatan trianggulasi yakni Observasi

Peneliti melakukan dua kali analis yang pertama analisis sebelum di lapangan dan kedua anaisis data di lapangan yang mana peneliti mengunakan Model Miles dan Huberman. Menurut Sugiyono (2016) sebagai berikut:

Analisis Sebelum di lapangan dilakukan terhadap data hasil studi pendahuluan, atau data sekunder, yang akan digunakan untuk menentukan fokus penelitian. Namun demikian fokus penelitian ini masih bersifat sementara, dan akan berkembang setelah peneliti masuk dan selama di lapangan.

Analisis data di lapangan, dilakukan pada saat pengumpulan data berlangsung. dan setelah selesai pengumpulan data dalam periode tertentu. Pada saat wawancara, peneliti sudah melakukan analisis tahadap jawaban yang diwawancarai. Aktivitas dalam analisis data, yaitu reduksi data, penyajian data dan conclusion drawing/verification.

\section{Hasil dan Diskusi}

Penelitian ini membahas tentang citra diri mahasiswi obesitas, Dengan subjek kategori obesitas, berusia 18-21 tahun, 
berjenis kelamin wanita yang berinisial, RA, RW, LM dan PA.

Keempat subjek merupakan mahasiswi UIN Raden Fatah palembang. Dimana subjek RA di fakultas psikologi, jurusan psikologi islam semster 5. RA mengaku sudah obesitas sejak SMP. Saat ini berat badan RA $94 \mathrm{~kg}$ dengan tinggi badan 160 $\mathrm{cm}$, yang artinya memiliki indeks massa tubuh (IMT) 29,3 yang termasuk kategori obesitas I. Sedangkan, RW di fakultas ushuluddin, jurusan akidah filsafat, semester 7. RW mengatakan sudah memiliki badan obesitas sejak berusia 6 tahun, RW mengatakan saat ini berat badannya $90 \mathrm{~kg}$ dengan tinggi badan 165 $\mathrm{cm}$, yang artinya memiliki indeks massa tubuh (IMT) 27,2 yang termasuk kategori obesitas I. Selanjutnya, LM di fakultas tarbiah, jurusan pendidikan biologi, semester 9. LM mengatakan sudah memiliki berat badan obesitas sejak SD, saat ini berat badan LM $80 \mathrm{~kg}$ dengan tinggi badan $153 \mathrm{~cm}$, yang artinya memiliki indeks massa tubuh (IMT) 26,1 yang termasuk kategori obesitas I. Sedangkan, PA di fakultas psikologi, jurusan psikologi islam, semester 1. PA mengatakan sudah memiliki badan obesitas sejak SD, saat ini berat badan PA $86 \mathrm{~kg}$ dengan tinggi badan $167 \mathrm{~cm}$, yang artinya memiliki indeks massa tubuh (IMT) 25,7 yang termasuk kategori obesitas I.

Berdasarkan hasil temuan penelitian yang dilakukan untuk mengetahui bagaimana citra diri mahasiswi obesitas dan faktorfaktor apa saja yang mempengaruhi citra diri mahasiswi obesitas pada subjek RA, RW, LM dan PA yang dilihat melalui beberapa hal yang berkaitan dengan tematema yang menggambarkan citra diri mahasiswi obesitas di UIN Raden Fatah
Palembang. Adapun tema-tema tersebut akan dibahas secara sistematis, sebagai berikut:

Pada tema pertama yaitu penerimaan diri, dari keempat subjek semuanya menerima keadaan dirinya, memahami kekurangan dan kelebihannya, subjek menyadari bahwa tubuhnya tidaklah ideal, namun subjek juga menyadari memiliki kelebihan dari dirinya. Menurut Grad (1996) orang lain menerima kita seperti apa kita menerima diri sendiri. Berusahalah merasa senang dengan diri sendiri seperti apa adannya dan kembangkanlah apa yang dapat kita berikan kepada orang lain, dan kita tidak merasa khawatir dangan masalah penerimaan.

Pada tema kedua yaitu kepercayaan diri, Keempat subjek merasa percaya diri. Menurut Supratman dan Mahadian (2018) saat seseorang memiliki kepercayaan diri, maka yang terjadi seseorang akan membangun image diri seseorang kepada orang lain, akan tetapi kurangnya kepercayaan diri membuat seseorang akan dianggap sebagai seorang yang memiliki posisi yang lemah. Menurut Rakhmat (2018) orang yang kurang percaya diri akan cenderung sedapat mungkin menghindari situasi komunikasi. Ia takut orang lain akan mengejek atau menyalahkannya. Sebagian subjek merasa percaya diri jika berada dilingkungan yang membuat meraka nyaman dan ketika berada dengan orangorang yang telah meraka kenal saja. sebagian subjek mengaku merasa sudah terbiasa dan nyaman dengan tubuh obesitasnya dan meyakini kemampuan yang dimilikinya.

Pada tema ketiga yaitu keinginan menjadi orang lain, keempat subjek mengatakan selalu menjadi dirinya sendiri dengan caranya masing-masing. Menurut Arinto (dalam Umam, 2013) citra diri yang positif 
pada seseorang dapat dilihat pada dimensidimensi prilaku yang ditunjukkan dalam kehidupan nyata, salah satunya adalah menjadi diri sendiri. Subjek menjadi dirinya sendiri dengan lebih mengenal dirinya. Keempat subjek tidak pernah ingin menjadi orang lain dan merasa sudah nyaman dengan dirinya dan tidak ingin menirukan orang lain. Menurut Susanto (2015) nyaman dengan diri sendiri dan orang lain mempunyai makna sebagai kondisi psikologis yang bersifat transparan, yaitu membiarkan diri sendiri dilihat orang lain dalam keadaan tertentu.

Pada tema keempat yaitu takut akan penolakan dan kegagalan, keempat subjek mengatakan pernah merasakan penolakkan dan takut akan kegagalan dalam kondisi dan situasi yang berbeda-beda, namun memiliki caranya masing-masing untuk mengatasinya. Penolakkan menurut Winch (2013) penolakkan juga berpengaruh terhadap kemampuan untuk menggunakan logika yang sehat dan pikiran yang jernih dengan cara-cara lain. Menurut Grad (1996) setiap orang menghadapi penolakan dalam hidupnya. Terimalah beberapa penolakan sebagai hal yang tidak terelakkan dan ketahuilah bahwa itu tidak berarti bahwa diri tidak layak, rendah, atau tidak diinginkan; itu hanya pernyataan prasangka dan pilihan orang lain.

Sedangkan rasa takut akan kegagalan, menurut Murray dan Atkinson (dalam Fadhillah \& Sakti, 2015) mengungkapkan bahwa ketakutan akan kegagalan adalah kecendrungan disposisional motif yang berbasis penghindaran kegagalan, karena seseorang merasa malu terhadap kegagalan. Ketakutan akan kegagalan mengacu pada sebuah dorongan untuk bertindak berlawanan dengan dorongan untuk berprestasi. Sama hal nya dengan salah satu subjek yang mengatakan caranya untuk tidak gagal adalah dengan meunjukkan prestasi yang dimilikinya.

Pada tema kelima yaitu putus asa, keempat subjek pernah merasakan putus asa, namun keempat subjek mempunyai caranya masing masing untuk tidak menyerah pada situasi dan keadaannya. Menurut Kandani (dalam Jago, 2013) merasa tidak mampu atau menyerah pada situas dan keadaan adalah salah satu dari karakteristik citra diri negatif pada seseorang.

Pada tema keenam yaitu perasaan tersinggung, dua subjek diantara keempat subjek, mengatakan jika tidak mudah tersinggung, namun bukan berarti tidak pernah tersinggung. Sedangkan dua diantara keempat subjek mengatakan tidak mudah tersinggung sama sekali. Perasaan tersinggung berkaitan dengan emosi yang dirasakan. Menurut Chaplin (2014) dalam Dictionaryof Psychology, emosi adalah sebagai suatu keadaan yang terangsang dari organisme mencangkup perubahanperubahan yang disadari, yang melanda sifatnya dari perubahan prilaku.

Pada tema ketujuh yaitu memiliki target hidup, dari keempat subjek, tiga diantaranya memiliki target hidup yang sama yaitu segera lulus kuliah. Sedangkan satu subjek yang masih semester pertama mengaku belum memiliki target hidup saat ini dan memilih fokus kuliah saja. Orang yang tidak memiliki target hidup adalah orang yang tidak memiliki tugas. Hidupnya hampa dan tidak memiliki makna (Jazuli, 2006). Dengan adanya target hudup, dapat memotivasi untuk menjalankan hidup.

Tema kedelapan yaitu merasa dihargai, dua subjek merasa dihargai orang lain. Merasa 
dihargai karena tidak hanya kekurangan dari diri yang dilihat orang lain, melaikan juga memiliki banyak kelebihan dan potensi. Menurut Goldstein (dalam Suryabrata, 2014) Untuk melihat potensi individu yang dapat dilakukan dengan mengetahui apa yang dipilih/diutamakan oleh individu dan apa yang dia dapat mengerjakannya paling baik. Sedangkan, salah satu subjek merasa ragu jika dihargai orang lain. Satu subjek lainnya merasa dihargai hanya dari orang-orang yang mengenalnya saja. Terkadang rasa ingin dihargai kerap muncul, dikarenakan dihargai orang lain dibutuhkan setiap individu.

Setiap orang yang menjalankan kehidupan sosial, pasti ingin dihargai, baik oleh orangorang disekitarnya maupun oleh diri sendiri. Ketika seseorang tidak dihargai orang lain akan membuat seseorang berkecil hati. Menurut Zuhdiyah (2009) setiap orang butuh dihargai dan ingin diperhatikan. Orang yang mendapat hinaan, dipandang rendah dan tidak atau kurang merasa dihargai akan menyebabkan ia merasa sakit hati hingga berusaha untuk mempertahankan harga dirinya dengan jalan apa pun.

Tema kesembilan pengalaman buruk selama memiliki badan obesitas, semua subjek mengalami pengalaman buruk selama memiliki badan obesitas seperti di hina dan di permalikan dengan cara memanggil dengan panggilan yang menyinggung badan mereka yang obesitas. Menurut situs Vamale (2015) tubuh gemuk seringkali membuat seorang wanita merasa minder dan tidak percaya diri. Apalagi, badan gemuk sering kali menjadi bahan hinaan orang lain. Bukan hanya malu hal ini akan membuat orang kecewa, minder dan marah.

Tema kesepuluh usaha menurunkan berat badan, semua subjek melakukan usaha penurunan berat badan, namun dari keempat subjek belum pernah berhasil menurunkan berat badannya. Menurut Santoso (2008) sering mendengar kata metabolisme saat membahas hal-hal yang berhubungan dengan berat badan. Orang yang gendut dibilang memiliki metabolismenya lambat, sedangkan orang yang kurus memiliki metabolisme yang sepat sehingga dapat bebas memakan segalanya. Faktor genetika menentukan seberapa cepat metabolisme.

Tema kesebelas kedekatan dengan teman, pada semua subjek masing-masing dapat menjealin kedekatan dengan teman dan memiliki banyak teman. Menurut Thalib (2010) bagi remaja akhir seiring dengan peningkatan kognitif dan kematangan emosional, kemampuan menjalin persahabatan dengan teman sebaya menjadi lebih tenang dan stabil dengan apresiasi perbedaan individual dan keunikan kepribadian terhadap yang lain yang lebih baik.

Hasil temuan peneliti tentang gambaran citra diri mahasiswi obesitas (RA, RW, LM dan PA) dilihat dari sebelas tema, yaitu penerimaan diri, kepercayaan diri, keinginan menjadi orang lain, takut akan penolakan dan kegagalan, putus asa, perasaan tersinggung, target hidup dan merasa dihargai, pengalaman buruk selama memiliki badan obesitas, usaha menurunkan berat badan, kedekatan dengan teman. Menurut Mangkuprawira (dalam Jago, 2013) menambahkan individu dengan citra diri positif, diantaranya 
individu yang memiliki citra diri yang positif merasa dirinya berharga di mata orang lain, kepercayaan diri individu, bahwa meraka memiliki lebih banyak kualitas positif bila dibandingkan dengan kualitas negatif dari dirinya sendiri. Selanjutnya, keempat subjek mengaku percaya diri, pernah merasakan penolakan dan takut gagal, namun dapat mengatasi keadaannya, tiga diantara keempat subjek, merasa nyaman dengan dirinya dan tidak ingin menjadi orang lain, dan hanya mencoba menjadi apa adanya. Sedangkan, satu dari empat subjek pernah merasa ingin menjadi orang lain, dengan alasan kesehatan, namun subjek merasa sealu menjadi diri sendiri dimana un dan kapan pun. Selanjutnya perasaan putus asa keempat subjek pernah mengalaminya dengan persoalan yang berbeda-beda, namun semua subjek tidak menyerah dan mengatasinya dengan caranya masingmasing. Selanjutnya, keempat subjek merasa tidak mudah tersinggung, namun bukan berarti tidak pernah tersinggung, semua subjek akan tersinggung tergantung kondisi dan keadaan dirinya. Hal ini selaras dengan uraian Kandani (dalam Jago, 2013:101), menguraikan orang dengan citra diri yang negatif, yaitu Minder (tidak percaya diri), Sombong (takut gagal, takut tertolak, pembuktian diri), Rasa tidak aman (ingin menjadi orang lain), Merasa tidak mampu (menyerah pada situasi ataupun keadaan) dan Mudah tersinggung.

Selain itu, peneliti juga mendapatkan faktor-faktor yang dapat mempengaruhi terbentuknya citra diri mahasiswi obesitas yaitu faktor keadaan fisik, faktor teman sebaya, faktor potensi dalam diri, dan faktor prestasi yang pernah dicapai. Semua subjek dalam penelitian ini memiliki tubuh obesitas yang mana mengakibatkan seringnya di perlakukan tidak baik oleh lingkungannya seperti di panggil dengan panggilan yang menyinggung badannya. Faktor teman sebaya, keempat subjek memiliki teman dekat yang dapat menerima keadaannya. Pada faktor potensi dalam diri, keempat subjek memiliki perbedaan dimana salah satu subjek yang memiliki potensi di bidang paduan suara, terlihat lebih banyak memiliki kualitas positif dalam dirinya. Sama halnya faktor prestasi pada salah satu subjek yang sama memiliki prestasi di bidang akademik maupun nonakademik, itu terlihat dari prestasinya yang selalu juara kelas dan memenangkan perlombaan paduan suara. Pada subjek yang memiliki prestasi terlihat lebih banyak memiliki karakteristik citra diri positif.

\section{Kesimpulan}

Dari hasil temuan yang telah dipaparkan dapat disimpulkan bahawa keempat subjek dilihat dari karakteristik citra diri memiliki lebih banyak kualitas positif bila dibandingkan dengan kualitas negatif dari dirinya, yang artinya bahwa keempat subjek memiliki citra diri positif, namun pada kondisi tertentu dapat menjadi citra diri negatif.

\section{Referensi}

Akhriani, M., Fadhilah, E., \& Kurniasari, F.N. (2016). Hubungan Konsumsi Minuman Berpemanis dengan Kejadian Kegemukan pada Remaja di SMP Negeri 1 Bandung. Indonesian Journal of Human Nutrition, 3 (1), 29-40.

Al-Maragi, A.M. (1993). (Eds). Tafsir AlMaragi. Terj. Juz VIII. Semarang: PT. Karya Toha Putra. 
Al-Maragi, A.M. (1993). (Eds). Tafsir AlMaragi. Terj. Juz XI. Semarang: PT. Karya Toha Putra.

Andarwati, I. (2016). Citra Diri Ditinjau dari Intensitas Penggunaan Media Jejaring Sosial Instagram pada Siswa Kelas Xi Sma N 9 Yogyakarta. E-Jurnal Bimbingan dan Konseling, 3 (5), 1-12.

Cahyono, S.B. (2008). Gaya Hidup dan Penyakit Modern. Yogyakarta: Kanisius.

Chan, R.S.M. \& Woo, J. (2010). Prevention of Overweight and Obesity: How Effective is the Current Public Health Approach. International Journal of Environmental Research and Public Health, 7, 765-783.

Chaplin, J.P. (2014). Kamus Lengkap Psikologi. Terj. Kartini Kartono. Jakarta: PT Grafindo Persada.

Devya. (2015). Hubungan Citra Diri dan Perilaku Konsumtif pada Remaja Putri yang Memakai Kosmetik Wajah. E-Journal Psikologi, 3 (1), 433-440.

Elfiky, I. (2009). Terapi Berfikir Positif. Terj. Khalifurrahman Fath \& M. Taufik Damas. Zaman: Jakarta.

Fadhlillah, H. \& Sakti, H. (2015). Hubungan antara Ketakutan akan Kegagalan dengan Intensi Berwirausaha pada Mahasiswa UKM Research and Business (R'nB) Universitas Diponegoro. Jurnal Empati, 4 (2), 182-186.

Grad, M. (1996). Karisma: Bagaimana mendapatkan keajaiban yang istimewa itu. Terj. Lyndon Saputra. Jakarta: Binarupa Aksara. Hanurawan, F. (2016). Metode Penelitian Kualitatif untuk Ilmu psikologi. Jakarta: PT RajaGrafindo Persada.
Harmanto, N. (2006). Herbal untuk Keluarga Ibu Sehat dan Cantik dengan Herbal. Jakarta: PT Elex Media Komputindo.

Hasanah, U. (2013). Pembentukan Identitas Diri dan Gambaran Diri pada Remaja Putri Bertato di Samarinda. E-jurnal Psikologi, 1 (2), 177-186.

Herdiansyah, H. (2014). Metodelogi Penelitiaan Kualitatif untuk Ilmuilmu Sosial. Jakarta: Salemba Humanika.

Holden, R. (2005). Success Intelligence. Terj. Yuliani Liputo. Bandung: PT Mizan Pustaka.

Irwan. (2016). Epokreologi Penyakit Tidak Menular. Yogyakarta: Deepublish.

Jago, D.M.Y. (2013). Citra Diri Perempuan dalam Antologi Puisi Perempuan Penyair Indonesia Terkini 2012: Sebuah Pendekatan Semiotika. Jurnal Ilmiah Kebudayaan SINTESIS, 7 (2), 97-113.

Jazuli, A.S. (2006). Kehidupan dalam Pandangan Al-Qur'an. Jakarta: Geme Insani.

Lutfiana, D. (2017, 10 Juni). "Bersyukur: Ibadah yang Seringkali Dilalaikan". Masjid Agung Trans Studio [on-line]. Diakses pada tanggal 10 Juni 2017 dari Error! Hyperlink reference not valid.

Maleong, L.J. (2017). Metodologi Penelitian Kualitatif. Bandung: PT Remaja Rosdakarya.

Maltz, M. (1964). The Magic Power of Selfimage Psychology. New York: Pocket Books.

Misnadiarly. (2007). Obesitas sebagai Faktor Risiko 
Beberapa Penyakit. Jakarta:

Pustaka Obor.

Ni'mah, U \& Rohmatun. (2017). Hubungan antara Kepercayaan Diri dan Pola Asuh Otoritatif dengan Citra Diri pada Mahasiswi yang Melakukan Perawatan Wajah di Klinik Kecantikan. Proyeksi, 12 (2), 6978.

Ningsih, E.D \& Jana, A. (2016). Hubungan Obesitas dengan Citra Diri dan Harga Diri pada Warga di Desa Gajahwongan Canden Sambi Boyolali. Kosala, 4 (2), 113-121.

Nur'afni, H. (2009). Diet for Muslimah. Bandung: PT Mizan Pustaka.

Oktarina, R., Mansjour, S.S., Astuti, A.D., Suparto, I.H. \& Sajuthi, D. (2010). Kajian Pakan Bersumber Energi Tinggi pada Pembentukkan Monyet Obes. Jurnal Biologi Indonesia, 6 (3), 383-392.

Pandu, S.Y. (2014). Konsep Diri Remaja Putri yang Mengalami Obesitas. Psikovidya, 18 (2), 107-131.

Prameswari, S.P.I, Aisah, S. \& Mifbakhuddin. (2013). Hubungan Obesitas dengan Citra Diri dan Harga Diri pada Remaja Putri di Keluarga Jomblang Kecamatan Candisari Semarang. Jurnal Keperawatan Komunikasi, 1 (1), 52-61.

Rakhmat, J. (2018). Psikologi Komunikasi. Bandung: PT Remaja Rosdakarya. Ramayulis, R \& Christine, L. (2008). 17 Alternatif untuk Langsing. Jakarta: Penebar Swadaya.

Rohman, J. \& Baidun, A. (2013). Pengaruh Citra Diri (Self Image) dan Konformitasn Terhadap Perilaku Compulsive Buying pada Remaja. TAZKYA Journal of Psychology, 18 (2), 281-297.
Rosmala, Z. (2006). Menu Sehat Sesuai Golongan Darah. Jakarta: Puspa Swara.

Santoso, D. (2008). Rahasia Diet: The Concept, The Diet, The Workout. Libri: Jakarta.

Sari, D.N. (2015). Hubungan Citra Diri Dan Kepuasan Konsumen Akan Merek Dengan Minat Beli Produk Bermerek Surfing. Ejournal Psikologi, 1 (3), 672-682.

Schachter, S. (1968). Ingestive Classics Stanley Schachter and Obesity and Eating. Science, 161 (3843), 751756.

Sitepu, D.L, Opod, H. \& Pali, C. (2016). Hubungan Tingkat Kepercayaan Diri dengan Obesitas pada Siswa SMA Negeri 1 Manado. Jurnal eBiomedik, 4 (1).

Sudargo, T., Freitag, L.M.H., Rosiyani, F. \& Kusmayanti, N.A. (2014). Pola Makan dan Obesitas. Yogyakarta: Gaja Mada University Press.

Sugiyono. (2016). Metode Penelitian Kuantitatif, Kualitatif, dan $R \& D$. Bandung: Alfabeta.

Supratman, L.P. \& Mahadian, A.B. (eds). (2018). Psikologi Komunikasi. Yogyakarta: Deepublish.

Suryabrata, S. (2014). Psikologi Kepribadian. Jakarta: PT Rajagrafindo Persada.

Susanto, A. (2015). Bimbingan \& Konseling di Taman KanakKanak. Jakarta: Kencana.

Thalib, S.B. (2010). (eds). Psikologi Pendidikan Berbasis Analisis Empiris Aplikatif. Kencana: Jakarta.

Umam, A.K. (2013). Citra Diri Pemimpin. Nizham, 1 (1), 68-82.

Vamale. (2015, 14 Agustus). "Dihina gemuk. Wanita ini tulis surat yang 
mengetarkan hati". [on-line].

Diakses pada tanggal 14 Agustus

2015

dari

https://m.vemale.com/lentera/852

80-dihina-gemuk-wanita-ini-tulis-

surat-terbuka-yang-

menggetarkan-hati.html.

Vonala, F.A. \& Ernawati, N. (2016).

Hubugan Konsep Diri (Citra Diri dan Harga Diri) dengan Strategi

Koping pada Penderita Pasca

Stroke di Wilayah Kerja

Puskesmas Kedungwuni I

Kabupaten Pekalongan.

Muhammadiyah, Pekajangan

Pekalongan.

Wibowo, H. (2007). Fortune Favors the ready, Keberuntungan berpihak kepada orang-orang yang Siap. Bandung: OASE Mata Air Makna.

Winarsi. (2010). Protein Kedelai \& Kecambah Manfaatnya bagi Kesihatan. Yogyakarta: Kanisius.

Winch, G. (2017). Pertolongan Pertama pada Emosi Anda. Terj. Th Dewi Wulansari. Jakarta: PT Pustaka Alvabet.

Wulandari, A.P. \& Aini, N. (2016). Hubungan Obesitas dengan Harga Diri (Self-Esteem) pada Remaja Putri SMA Negeri 13 Semarang. Jurnal Keperawatan Soedirman, 11 (2), 81-89.

Yusro, N. (2017). Urgensitas Kepribadian Da'i dalam Berdakwah. Jurnal Dakwah dan Komunikasi, 1 (1), 73-100.

Zuhdiyah. (2009). Psikologi Agama. Grafika Telindo: Palembang. 